\section{THE BLENDING OF THAI- MUSLIM MUSICAL PERFORMANCES IN SOUTHERN THAILAND}

\section{Bussakorn Sumrongthong ${ }^{1}$}

\section{Abstract \\ Introduction}

This paper is a research report of investigative fieldwork on the musical culture of the southern provinces of Thailand. The research was conducted by interviewing prominent musicians from each of the following provinces: Chumphon, Krabi, Nakhon Si Thammarat, Phang-Nga, Phatthalung, Phuket, Satun, Songkhla, Surat Thani and Trang. The current political instability in the provinces of Pattani, Yala and Narativas prevented conducting research in these locales.

The process of this qualitative research consisted of direct observation, in-depth interviews of well-known artists, a survey of musical instruments and related performance or ritual materials /documents. The research found that the culturally significant music and performances in this region can be divided into 2 socio-religious groups delineated by the Buddhist and Muslim faiths.

The core songs and performances of the Buddhists are: Ka Lo, Nang Talung, Nora, $P h o n$ and $\mathrm{Li} \mathrm{Ke} P a$, while the key classical Thai songs are Phleng Ruea, Phleng Bok,

\footnotetext{
${ }^{1}$ Associate Professor, Department of Music, Faculty of Fine and Applied arts, Chulalongkorn University, Bangkok, Thailand
}

Phleng Na and Phleng Tak. Those of the Muslim groups are: Rong Ngeng, Ma'yong, Dikia, Li Ke Hulu and Sila.

This article will present information only about the music and performances of the Muslim social group as the Buddhist related research is covered in a separate article. This report will focus on the key elements and characteristics, succession of musical knowledge, rituals and beliefs, including the knowledge succession of each musical performance.

\section{Musical culture of southern Thailand}

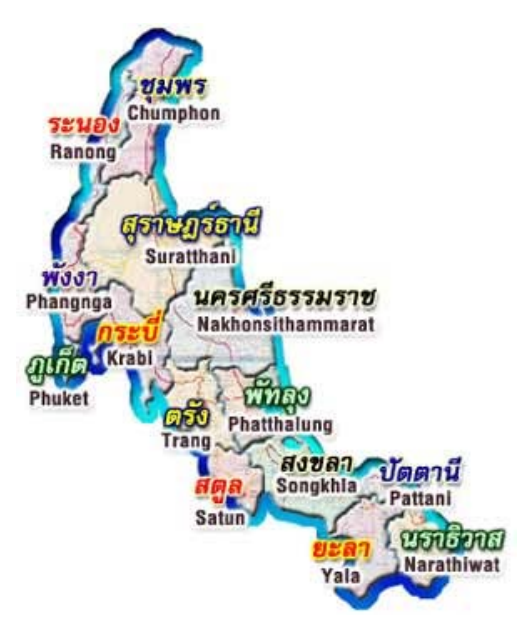

Figure 1: Map of Southern Thailand

Historically, the South of Thailand has been a commercial trading center of South-east Asia. It served as a hub between the two great nations of India and China and as a result, facilitated the dissemination of both Brahmanism and Buddhism in this region.

The arrival of many different nationals and especially those from India strongly influenced the local musical culture and theatre. Though the influence is likely to 
have been mutual with both the locals and the new arrivals influencing each other, there were elements of the Southern Thai Nora melody that became altered from contact with Indian musicians. In particular, the rhythm and manner of playing the pair of drums in this song conveys the strong influence from India's musical heritage.

The historically close relationship with the Muslim population from Malaysia in this region has also had an effect on the development of the local Southern Thai music. Geographically Malaysia lies along Thailand's southern border. Initially, Thai - Malay affairs mostly concerned politics and warring power struggles. However, when the Malays and some Southern Thais in the border areas converted from Buddhism to Islam, they were brought culturally closer via a shared religion. Moreover, considering the long term linguistic and racial blending, a good percentage of the Southern Thais speak Malay and carry a Malay bloodline and vice versa for the northern states of Malaysia where the Thais have become intermixed. The musical culture in these areas mirrors this ethnic blending and the two countries have many characteristics in common. It can be said that the local music in the Southern Thai areas is predominately in the Java-Malay style. An instrument that demonstrates this blend is the incorporation of the Java-Malay's small one-sided drum known as the Rammana.

Furthermore, this style is not just restricted to the border provinces areas; some instruments are widespread throughout Southern Thailand. The tracing of the migration of the Rammana and the Pi Ho (oboe) instruments are examples of this dispersion.
Additionally, the Southern and Central regions of Thailand have maintained a strong artistic relationship over the centuries. Nakhon Srithammarat is the city that is and was considered the cultural center of Southern Thailand. Its performance arts and music were so highly developed that it was nicknamed "The city of dramatic performance" (Mueang Lakhon).

The performing arts and music of the city always had an influence on Central Thailand such as in the Thonburi period (1768-1782). At this time, King Taksin requested that the plays from Nakhon Srithammarat be performed in Thonburi which was the capital of Thailand. However, this region's culture was also shared as far as the South as well. For example, the Pi Nok (oboe), So Duang (high pitched vertical fiddle) and $S o U$ (low pitched vertical fiddle) from the Thonburi Royal court migrated to Southern Thailand. Over time these have become common instruments in the ensembles of this region.

According to Sujarit Buapim (1995: 25) who researched the origins of music in this region, the Southern local song has been influenced by the different cultural groups that resided there as result of the trade relationships with India, Java (Indonesia) and Malaysia. There was also a secondary influence with Central Thailand since Thais travelled south to receive and further distribute the trade goods imported from abroad.

When reviewing in detail the former prominent local melodies that are played in Southern Thailand there is not any one song that one can ascertain as originating from this region (excluding the remote indigenous tribes). The songs are either 
from Malaysia or Central Thailand. Some, however, have southern names, for instance, the songs of $\mathrm{Ka} L o$, Rong Ngeng and $L i$ ke Hulu are Java-Malay cultural derivatives. In addition, later on with the growing impact of Western Classical music during the Victorian Era (18391901), the violin was incorporated as accompaniment to the Rong Ngeng and Sampeng dances.

In general, it can be said that the Southern Thai musical culture has developed primarily through the inclusion and incorporation of music and instruments from outside its own region. Its music is therefore defined by how it has chosen to include, modify or blend outside influences both into and on to its existing musical base. The Southerners have created their own unique cultural identity by mixing the received musical impetuses with the traditional one while maintaining the core local rhythm that retains the listeners feel for the original southern ambiance.

An exception to the generalized musical blending during this period is to be found in the musical originality and consistency of the remote rural areas where the Sakai tribe resides. The Sakai people are an indigenous member of the Semang ethnic group. The stable characteristics of their local music are reported to have resulted from their isolation since they were far removed from both the main trade centers and their routes. Consequently, their unique musical identity was well preserved since there was minimal external influence.

\section{Music, performances and rituals of Thai-Muslims}

\section{The Rong Ngeng}

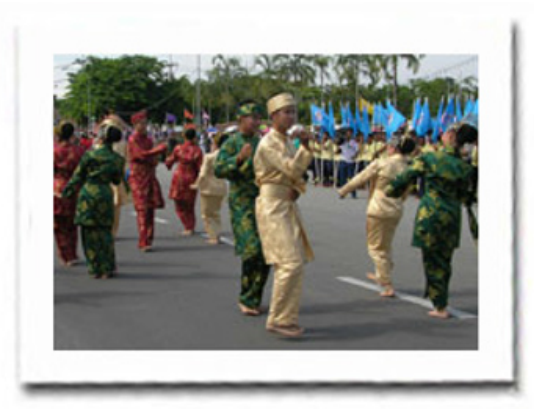

Figure 2: Rong Ngeng ${ }^{2}$

The Rong Ngeng or Rong Ngeng Tanyong is a folk performance of Thai Southerners who live on the west coast in the Trang, Phang-Nga or Phuket districts. It typically consists of 1-2 performers who sing and or dance in a "call and response" manner. When there is one main singer, the response portion can be provided by a backing group of singers or informally by members of the audience. Additionally, since it is a community performance, spontaneous audience participation is common as well. It is popular amongst both Buddhist and Muslim villages.

The characteristics of the Rong Ngeng are evidently a mixture of the local southern Thai and Malaysian cultures with the use of Malay words in the lyrics and the merger of Malaysian rhythm sets. The Malaysian song that accompanies this performance is called The Tanyong song because each line of the lyrics always

\footnotetext{
${ }^{2}$ From $<$ http://learners.in.th/blog/ dramatwo $2 / 70125$ [2/02/2009]>
} 
starts with "Tanyong Tanyong..." Tanyong is the name of a specific regional flower.

It is hard to identify precisely when the Rong Ngeng first appeared. However, from interviewing the elders of the Kantang district of the Trang province, it can be ascertained that this performance has been handed down from generation to generation. In the terms of its background, there are two theories of how it was brought to Southern Thailand.

The first states that it came with the Royal court and later spread to the general population through a Ma'yong performance. ${ }^{3}$

The second idea is that the now popular Rong Ngeng dance was historically primarily dominated by the Malays in the west coast towns. The performance was brought to this region in the Lanta district of the Krabi province, and performed by the Hua Lam people whose relatives resided in the Malaysian city of Penang.

\section{Key elements and characteristics}

In the beginning, only singing and dancing were included in this performance. There was no instrumental accompaniment. The

\footnotetext{
${ }^{3}$ Ma'yong is a healing or well-wishing ceremony. e.g. assisting a fellow citizen suffering from sickness or a ceremony to help ensure that a child gets accepted into the right school. As a side note, Ma'yong is also the name of the person whom conducts it. (Salae 1999: 5934-5936.)

Notice: In The Southern Thai Culture Encyclopedia the used term is Mak Yong.
}

lyrics were in the Malay language, which was difficult for the local Thai audience to understand. Consequently, the lyrics were eventually adapted into Thai with the inclusion of the So $U$ and the small singled-sided Rammana drum instruments to help energize the dancing. In today's Rong Ngeng band the So $U$ has been replaced by a violin and sometimes a Western style tambourine will be used if a Rammana is not available.

The Rong Ngeng that first came to the people of Southern Thailand's west coast is quite different from the original Malay version. Only fragments of the melody and dancing remain the same. Furthermore, with the lyrics having been translated into Thai, it is even more distant. However, like the original Malay performance the verses are sung in an improvised question then answer manner between the female and male dancers.

This popular performance hasn't just been limited to the Thai-Muslim communities but it is also enjoyed by the ThaiBuddhists in the area. This is made evident by the fact that for an ordination or auspicious ceremony the Thai-Buddhists often hire a Rong Ngeng band to accompany their ceremony while most of the dancers are Thai. The Malay Rong Ngeng performers sing the translated Thai version of the lyrics. The Rong Ngeng therefore, is a clear example of the blending of the Thai-Muslim and ThaiBuddhist cultures.

\section{Rituals and beliefs}

The Rong Ngeng artists, said that before one can learn how to perform the Rong Ngeng songs and dances, one has to perform a special rite. This type of rite is what the Thai people refer to as a Wai 
Khru. The term Wai Khru is a general term that refers to ceremonies surrounding mancreated endeavors such as music, theatre, instrument making and building construction. The three main focuses of Wai Khru's are as follows:

- To formally request to commence studying with one's selected music teacher.

- To honor and show respect to one's teacher and all teachers throughout history.

- To request permission from musical entities and land spirits, to apologize for mistakes and to ask for their assistance in ensuring a successful performance.

For the prospective Rong Ngeng student, holding a Wai Khru symbolically informs the teacher that the student wants to be under his tutelage. The locals believe that it is more auspicious to hold this ceremony on a Thursday. The core offerings at this ceremony consist of a cooked whole chicken, 125 baht in money, 3 betel nuts and 3 betel leaves. The quantity of these items varies from instructor to instructor but usually follows the same quantities that the teacher used during his own ceremony when he was an upcoming student. The items can vary depending upon the beliefs of the individual artists and communities. The teacher first guides the student in arranging the offerings and then he repeats passages in the Yawi language that are believed to be magical. Yawi is a Malaysian dialect spoken in Southern Thailand. The repetition of the traditional Yawi words symbolizes that the teacher has accepted the student as his pupil.

Moreover, before each performance, there is a Wai Khru held to honor all music teachers, apologize for any misdeeds and to inform the guardian spirit of the land where the stage is placed that that day a Rong Ngeng will be held. Also incorporated in this ritual, is a request for protection from the holy entities. The artists believe that if they don't perform this ritual to honor the teachers then bad things will happen. For example, they may become ill or will have a stomach ache and will not be able to carry on. They feel they need to perform the ritual to avoid any mistakes or accidents that would otherwise tarnish their concert. The offerings in this ritual are betel nuts and leaves with a token amount of money, which are provided by the host who hired the ensemble. The leader of the band is the one who conducts this Wai Khru. The aim of this ceremony is to apologize in advance (in case any mistakes occur during the concert) and to inform the guardian spirits along with the holy entities that soon the Rong Ngeng will be performed and to please protect them all. The language used in the ritual can be Yawi or the local dialect depending upon the leader's preference.

Based on an interview with Jew Pramongkij ${ }^{4}$, if there is any mistake or problem during the concert or a musician gets sick or the leader forgets to place an offering they invite the village medicine man to clear out the bad spirits or the entities that caused it. Then they need to conduct a Wai Khru ceremony as an apology ritual since it is believed that the spirit of the Rong Ngeng teacher is punishing them.

\footnotetext{
${ }^{4}$ Jew Pramongkij is a Rong Ngeng Master, Phuket Province. The interview was conducted on March 13, 2007.
} 


\section{Knowledge succession}

Most current Rong Ngeng performers have been raised in families whose elder members are Rong Ngeng artists. Occasionally, a child is inspired by listening to and appreciating a performance from his/her neighbor or he/she has had the opportunity to see it at a local fair. The detailed knowledge and background of the Rong Ngeng is transferred by word of mouth in the oral tradition from parents to child or from teacher to student. The mirroring or imitation instructional method is used. That is, the teacher performs first and then the student follows, attempting to match it. In addition, the student also attends live performances with his teacher. This, along with the caring one-on-one instruction, gives the student confidence and provides him with the chance to model his public performing skills as well.

Today's current Rong Ngeng artists consider that there is a lack of interest among the young generation in the Rong Ngeng and they are concerned that the Rong Ngeng will soon become extinct. Two factors, which makes the Rong Ngeng less accessible to the young are the difficulty or skill level required in its performance and the lack of understanding of Mawi or their own local dialect. As a result, currently there are not many young people left to carry on this tradition and the situation worsens with each death and retirement of the current Rong Ngeng artists. Together these factors has contributed to the disappearance of many of the Rong Ngeng bands and, nowadays, it is very rare to find one that compares in popularity with the past generations. ${ }^{5}$

${ }^{5}$ This is based on interview with La Habyuso on February 27, 2007

\section{The Ma'yong}

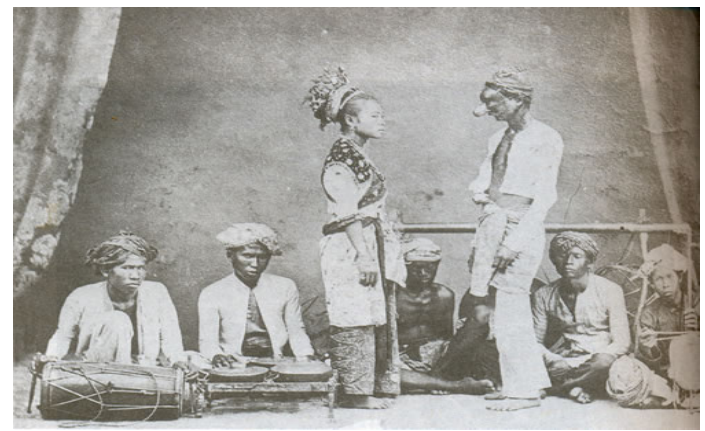

Figure 3: Ma'yong ${ }^{6}$

The Ma'yong is an ancient theatrical dance drama that dates back more than 1,000 years with influences extending from Indonesia, India and Malaysia. It was originally under the patronage of the royal courts in the Malaysian province of Kelantan. Then, eventually, in the 1900's, it evolved as a folk drama with an allfemale cast and 12 enduring stories musically supported by an ensemble consisting of the following: a vertical fiddle (Rebab), two gongs (Kong) and a pair of double-headed drums (Gendang). Vocally, there is a chorus with a solo voice that combines heterophonically with the Rebab resulting in the music having a Middle Eastern character. Heterophony results when variations of the same melody are played at the same time.

The Ma'yong's Islamic influences are evident when it is compared to the melismatic songs of the religious choral groups of Malaysia. Its Indonesian elements are reflected primarily from the Wayang Kulit shadow theatre where there

\footnotetext{
${ }^{6}$ From $<$ http://www.oknation.net/ blog/yongyoot/2007/08/22/entry-1 [2/02/2009]>
} 
are similarities in the participants, props and musical structure. It is unclear precisely how certain Indian songs and instruments such as the oboe (Pi Suna) and double-headed drum (Gendang) migrated to Malaysia and eventually into Southern Thailand. One theory is that they came along with the Pandjt tales of Java and then migrated north through Indonesia. The advent of international trade via sailing ships offers additional possibilities. In the Gerela state located in southern India, there is still a type of street theatre called "Yatri" or "Chatri" which is believed to be the origin of the Nora and Ma'yong. The gist of the artists' interviews suggests it has been found that the Ma'yong has the same characteristics as a Manora or Nora performance in the Southern Thailand. The main purpose of these performances is to entertain the audience while also making a votive offering to reverse one's bad luck.

\section{Legend of the Ma'yong}

There is a story about a couple that refers to the origin of the music and the Ma'yong. It is said that when a wife was ill, her husband brought her to many doctors but they could not cure her. Finally, in his desperation, he took her to see the medicine man. He examined her and was familiar with the ailment that had made her ill and how she could be cured. He told the husband that to cure his wife he had to search for a drum because its sound would be able to cure his wife's illness. The husband first searched for wood to make the drum. The drum he invented was one-sided and was covered with leather. He beat it so that his wife could hear its healing sound. She soon regained her health. Later when the couple went into the forest to hunt for oxen they made a fiddle to accompany them. They used the bone of an ox to make a bow, a half of coconut shell to make the fiddle's body and also the leather from the stomach of the ox to cover the coconut shell resonator.

When they had completed the fiddle, they brought it with them into the forest and named it Rebab. There, the couple played the fiddle and beat the drum. While they were playing the instruments, a monkey heard the sound of the fiddle as Yongday Yongday. He came to dance to their music and the wife remembered his many unique postures. Later when the couple came to the village they showed the villagers the monkey's dance with the accompaniment of their Rebab fiddle. The villagers enjoyed it so much that the couple hit upon the idea of collecting money for their audience's admission. Their show became very popular and was soon widely known.

It is also reported that the name Ma'yong may have been derived from the altered pronunciation of the Muslim god of rice Makhiang who was honored each year with performances. A second theory is that the Ma'yong is simply named after its leading actor who is also known as Ma'yong.

\section{Key elements and characteristics}

The Ma'yong is commonly performed upon many different occasions; for example, during a circumcision ritual, a harvest festival, a wedding ceremony, a governmental fair or other personal event where the band is hired by the host. Apart from this, it is a show to make a votive offering to remove one's bad luck or to ensure good luck. An example of a votive offering is when if one is sick making a promise to the spirit(s) that if one recovers, one will show one's appreciation 
by holding a Ma'yong in gratitude to them. Another example is making a simple wish and if it comes true, one hosts a Ma'yong as a tribute to the spirits responsible for the positive outcome.

According to tradition, the stage for the Ma'yong is a single-purpose stage that is specially built for each performance and no other theatrical or musical event besides the Ma'yong can be performed on it. There is also a special Wai Khru ceremony held before commencing its construction as well a specific order of tasks to be followed.

In its present day form, the Ma'yong performance has seen the addition of more instruments beyond the original drum (Gendang) and fiddle (Rebab). A double reed oboe (Pi Suna), a pair of high and low pitched gongs (Gelnang), a drum pair (Thon - in lieu of the original single Gendang), a small pair of wooden clappers (Cerek or Trae) used by the chorus vocalists are all typically found in the modern Ma'yong.

\section{Rituals and beliefs}

Before the actual Ma'yong performance, there is a Wai Khru ritual to honor the music teachers. The band requests the head shaman, who is known as the Bawmaw, to conduct the proceedings. It is similar to the pre-performance Wai Khru of the Rong Ngeng described earlier. The host acquires and prepares all of the offerings. Specifically they are, betel nuts, betel leaves, cigarettes, thread, rice, water, candles, bananas, incense and money.

The orientation and placement of the participants is significant. The Bawmaw (master of this ritual ceremony) will sit facing East during the ritual while all the performers and musicians sit in a circle around him. During the ritual, they will pray and pay respect to the guardian spirits, angels and other entities like the land or house spirits. This ceremony is a way of informing the spiritual world while also asking for their permission and assistance to ensure the bands success.

This prelude rite of honoring of the teacher before the Ma'yong is similar to those held prior to other performances in the South such as the Nora, Nang Talung and Li ke $\mathrm{Pa}$. The one essential thing they all must do in the Ma'yong and the accompanying ensemble is that they have to place candles at significant positions. They are placed at the center column of the stage and at the position of each instrument. Then the Ma'yong band will play the $\mathrm{Koh} P \mathrm{~Pa}^{-}$ Ngung overture since it is known as the teacher's song. Afterwards, they are free to play the other songs that make up the Ma'yong performance.

\section{Knowledge succession}

The details and the body of knowledge related to the Ma'yong performances are transferred from generation to generation by rote learning. Generally, the Ma'yong has a strong bloodline continuity where the professional Ma'yong performer seeks, encourages and trains a younger relative. However, with the younger generation being further removed from the everyday usage and understanding of the Malay language, this hurdle has added a large measure of difficulty to today's youth maintaining an interest in learning the Ma'yong. This reduced interest has translated into the Ma'yong being at risk of extinction in the near future. In addition, there is no governmental support for the Ma'yong or any cultural preservation program that includes it. 
Currently, nearly all of the existing Ma'yong bands, seem to only have older performers and they are held on increasingly rare occasions. The predicted loss of the Thai-Muslim Ma'yong performance will become true if it continues at this present low level of attention.

\section{The Dikia}

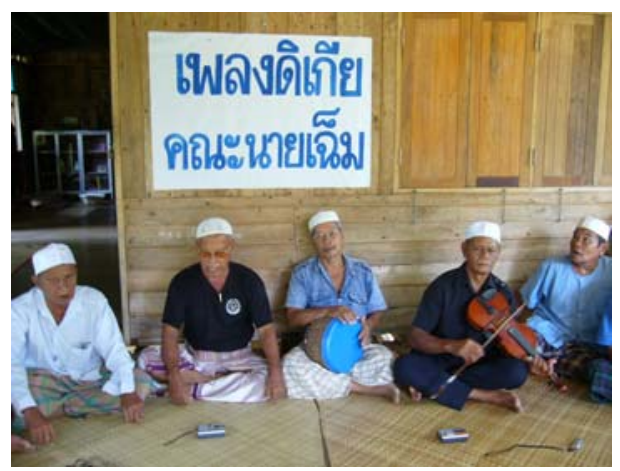

Figure 4: Dikia

The Dikia is a local performance whose original purpose was to bless a wedding couple and it is sung on other occasions for enjoyment. The melody of the Dikia is from Malaysia with influences from India while the present day lyrics are in Thai. The word "Dikia" is a Persian derivative and refers to the praising of God or a praying song known as "Dikia Maolid".

\section{Key elements and characteristics}

A Dikia ensemble consists of 10-15 artists and is made up of the following: one to two leading singers with five to eight for the chorus, one violin and two drummers. One drum is called Rammana and the other is known as Thon.

The Dikia is a performance without any dance or theatrical body movements. By having the singers and the musicians all sitting, emphasis is put on the story. The type of story depends on the intended purpose of each performance. During a wedding ceremony the Dikia's lyrics serve both to instruct and bless the wedding couple at the same time. Its intention is to guide them in how to be happy and behave in a moral manner. It also guides the couple as to how to be reasonable and moderate so that they will live happily together as well as to work hard to be prosperous. The purpose of the Dikia song is to remind the listener that he can improve himself by thinking, speaking and doing good while being reminded of the fundamentals of Islam. The Dikia serves as a persuasive vehicle to help convince people to be good and to do well.

\section{Rituals and beliefs}

According to the 71 year old Dikia song Master Chem Karnrieb from the Yao island district of Phang-Nga province, before the main performance of the Dikia itself, a song must be sung to bless the audience along with a blessing to god. It is then followed by the main teaching song and then the Dikia ends with the same blessing song being sung once more. Master Chem Karnrieb states that when he first began to study with Master Air Romin, he had to first receive a "Do-ah". That is, a wish from God. He also mentions that during the latter portion of the Dikia's initial blessing song, his hands would flow down his face in an approving manner as if they were god's. ${ }^{7}$

\footnotetext{
${ }^{7}$ Information is based on an interview with Chem Karnrieb, Dikia Master of Phang-Nga Province, on March 13, 2007.
} 


\section{Knowledge succession}

Master Chem Karnrieb studied with Master Air Romin for 10 years before he was allowed to conduct his own complete Dikia wedding ceremony song series. Furthermore, Master Chem Karnrieb was his only student who received this specialized series of wedding ceremony songs because there was no one else interested in this traditional way of singing. Moreover, he continued to enhance and practice his Dikia knowledge with the song masters in Phuket and Krabi. After this exchange period, Master Chem Karnrieb came back to teach and persuaded his interested relatives to set up his own band named "Dikia Nai Chem". He provides a role model for the younger generation in passing his knowledge about the Dikia song series to his offspring and the students at the Yao Island Witthaya School. The instructional sequence he uses is to first have them listen to the song he sings, then he lets them read the lyrics, work on their memorization and then has them follow his demonstrated examples. He emphasizes to them the importance of following the original model which he was taught as a youth. The first song Master Chem will teach them is the song for the wedding couple.

Master Chem Karnrieb has a strong desire to see his descendants and other young Thais realize the importance of the Dikia series of songs. It is his hope to see them take care of and continue this performing arts ritual with its associated beliefs to the next generation.
The Li ke Hulu

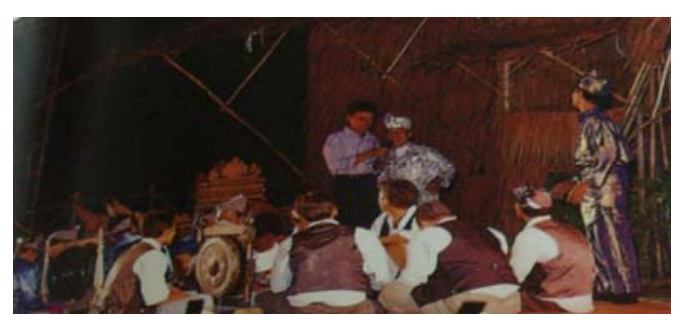

Figure 5: Li ke Hulu ${ }^{8}$

The Li ke Hulu is reported to be derived from the Zikir word which means the rhythm of reading prose while the word Hulu means south or in a southerly direction. Putting the two together means the singing of prose in the rhythm of a poem in the Southern Thai manner.

The Li ke Hulu is a folk performance of the southern border provinces that is very popular among Thai-Muslims. It is often been performed at the following ceremonies: weddings ( $\mathrm{Ma} \mathrm{Kae} \mathrm{Pu} \mathrm{Lo}$ ), circumcisions (Sunad) and other Islamic services.

\section{Key elements and characteristics}

The word Li ke is of Persian derivative and refers to an improvised retorting or dialog poem that is primarily performed in a band called Li ke Hulu. Some report that it came from the minority Sagai Semang tribe and it was called Manora Sagai. They also state that it has been loosely blended with the Central Thai styled antiphony (Lamtat) or a "call and response" style. The Li ke Hulu's "call and response" is only between the drum and the singers.

\footnotetext{
${ }^{8}$ From The Southern Thailand Culture Encyclopedia 14 (1999)
} 
There is no "dialog" of "call and response" between the singers themselves.

The Li ke Hulu ensemble consists of about 10 singers in the chorus with 2-3 leaders. Sometimes a singer, who is not a member of the band, will also join in with them. In other words, any person in the audience who feels like joining with the band may be allowed by the Li ke Hulu ensemble to perform with them. This is similar to the Pleng Bok performances of Thai Buddhist's in Southern Thailand.

The performance stage for the Li ke Hulu is raised to about 1 meter above ground level. It is an open platform without any curtain or additional set. The chorus will sit in a half circle at the back of the stage facing the audience. They sing along while clapping their hands and moving themselves to the rhythm of music. The lead singer who recites the poems will stand to one side of chorus circle. If there is a band competition or duel then all the bands will sit on the stage but each in their own separate circle. The bands will then take turns performing an attack and then a defense number which provides a lot of entertainment for the audience.

The instruments in the $\mathrm{Li}$ ke Hulu ensemble are, at minimum, 2 Ramana drums, 1 gong and 1-2 pairs of maracas. There may be a flute accompanying the chorus. The music will stop when the singer commences a song as in Thai-style antiphony or in the Choi (a type of Thai folk song). Each type of rhythm has its own style of lyrics. That is to say, each style of lyric is paired with its original rhythm and it cannot be performed with any other rhythm.

\section{Rituals and beliefs}

As in other performances mentioned previously, before each $\mathrm{Li}$ ke Hulu can begin, the participants need to commence with a Wai Khru ceremony to honor, pay respect to and remind themselves of their god Allah and their teacher(s). Some Li ke Hulu bands perform a special honoring song to show respect to their teachers before performing other songs. Furthermore, some of the written sources mention that, in the past, there was an additional ceremony held before $L i k e$ Hulu band competitions. It consisted of appeasement offerings to recruit the spiritual entities to help them to become victorious over their rival.

\section{Knowledge succession}

About 30 years ago it was common for Thai Li ke Hulu artists to spend a month studying with the Li ke Hulu masters in the Malay Kalantan province. While there, many hours of practice were needed to commit the songs and melodies to memory as well as the words in Malay. Afterwards, many artists came back and taught their offspring before setting up their own $\mathrm{Li}$ ke Hulu band and commencing their family's performing careers.

In the semi-recent, pre-TV past there were no female performers in the Li ke Hulu band. However, early on, one TV program featured a $\mathrm{Li}$ ke Hulu that consisted of female actors and ever since that time the Thai-Muslim Li ke Hulu ensembles have begun to include female actors. Nowadays, the Li ke Hulu remains very popular in Thai Muslim areas such as the Yala, Pattani and Narathiwat provinces but it is rare in all the others. 


\section{The Sila}

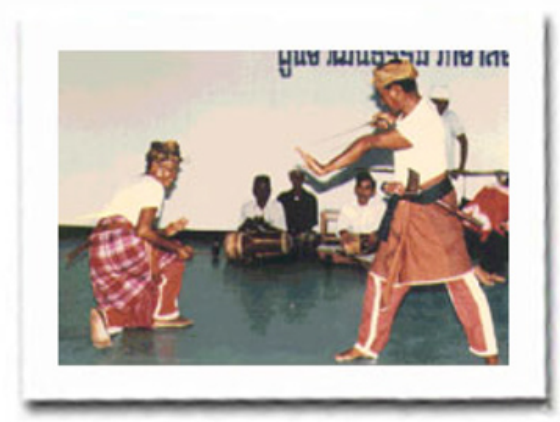

Figure 6: Sila ${ }^{9}$

Sila is known as a performance of selfdefence. It is an ancient martial art which can be found in the Southern part of Thailand. This type of martial arts performance can be traced back over thousand years and is known among Southeast Asian countries as "Pencak Silat". This fighting style exists throughout the Malay Archipelago, which includes Indonesia, Malaysia, Southern Thailand, the Southern Philippines, Singapore and Brunei Darussalam.

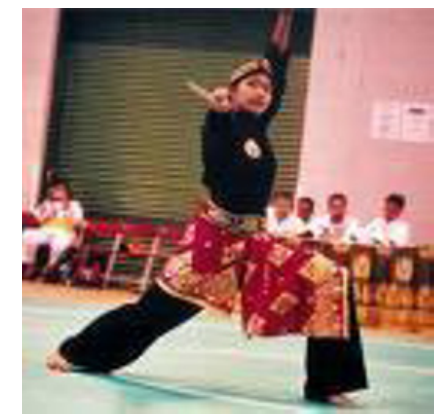

Figure 7: Pencak Silat ${ }^{10}$

\footnotetext{
${ }^{9}$ From <www.pocnara.go.th/naracity/pic/ Culture/seerah.jpg [2/02/2009]>

${ }^{10}$ From $<$ www.themartialartsjournal.com. $[2 / 02 / 2009]>$
}

Master Safak Nokkasem, a 64 year old Sila artist from the La-Ngu district in the Satun province of Thailand explains that the Sila is an empty-handed type of ThaiMuslim martial arts dancing with the emphasis on gorgeous movements. It is similar to Karate, Judo or the Thai-Muslim style of boxing in that they consist of combat movements without any weapons. In the South it is known as Dika or Buedika while in Satun province, it is known as Sila. However, in some parts of the South where there is the use of a dagger in the dance, it is called Kayo or Kayong. Sila schools in some locations are different in structure, technical movements and performing styles.

\section{Key elements and characteristics}

The musical instruments that accompany the Sila performance consist of a small drum (Thon), a small gong (Mong) and an oboe $(P i)$. The Sila is generally performed during a wedding ceremony and other auspicious ceremonies. While there are 12 dance poses in the Sila, the songs are only based on one melody.

\section{Rituals and beliefs}

In terms of the rituals and beliefs of the Sila, Master Teacher Safak reports that the student performs a Wai Khru ritual to honor the teacher before commencing his studies with him. The offerings in this ceremony are the following: 1 whole cooked chicken, 12 candles, popped rice and flowers and money in the amount of 150 baht. The new student must be at least 15 years old.

When the student wants to publicly perform the Sila, he must perform another ritual to honor the teaching spirits by offering the following items: a white cloth, 
a variety of rice called Sama-Ngad, white thread, and 1 finger ring. Then there is an honorary dance to the teacher that follows the offerings. During this dance the performer softly repeats some phrases. They are lines to a spell in Arabic, which contains the 4 wishes of the student. It has been translated as follows:

1. Wishing that they could forgive their competitors

2. Wishing that they will be safe from their enemies.

3. Wishing that their neighbors will be fond of them.

4. Wishing that they will have many admirers.

\section{Knowledge succession}

As a child, Master Teacher Safak was inspired to study the Sila by watching it being performed. Later on, when he was 15 , he began to study the Sila with his first teacher, Master Nai Bun (his last name is unknown). In addition to Sila dancing, Master Teacher Safak can also play all of the instruments. Currently, his band, known as Phuyai Khiaw, is the only one in the region.

Master Teacher Safak has been invited to represent Thailand internationally to demonstrate the Sila in the Malaysian city of Penang. He is currently an instructor at the Nakha School where he reports that most kids hardly pay attention to the Sila since they do not realize the value of it. However, in his efforts to preserve a high standard and a continuation of the Sila into the future, only the top student in each of his classes receives a ring that symbolizes his qualification to teach others the Sila. Furthermore, he wishes more people studied this kind of classical performance and had the time to practice it more so that it will not be lost to the future generations. ${ }^{11}$

\section{Comparison of the Wai Khru ceremonies}

In terms of the rituals and beliefs, there are Wai Khru rituals for worshiping deceased music instructors/artists and one which consists of the request from a novice student to study with his chosen instructor. The third one is for honoring ones teacher prior to performing. The performers conduct this latter ceremony to express both a sense of gratitude as well as to request permission to perform the selected pieces. It specifically expresses the appreciation for all the past teachers who have developed this musical and performance knowledge. They also believe in holy entities such as guardian spirits. For example, before a performance the artists must conduct a ritual where they make a request for protection and express a wish for happiness as well as success. However, the artists believe that if there is a mistake in carrying out the ceremony, some misfortune will befall them.

In addition, after the Dikia and Li ke Hulu performances there is a second Wai Khru ritual to worship and acknowledge one's teachers and their goodness.

For the Ma'yong performance there are two other distinctions. In its Wai Khru to honor ones teacher it is required to have a "Bawmaw" present to represent the performance group where he/she serves as the communicator with the holy spirits. Secondly, there is an additional ceremony where the permission to perform the

\footnotetext{
${ }^{11}$ Information from an interview with Safak Nokkasem on February 27, 2007.
} 
Ma'yong at this specific stage and location from the local earth guardian spirits is requested.

For the Sila, its Wai Khru ritual is slightly different from the others since the Sila consists of fighting. Besides making a wish to the holy entities to be well-liked and safe from harm in the stylized competition, the performer has to forgive his rival in advance.

\section{Conclusion}

The research found that most Thai-Muslim performances contain strong cultural influences from Malaysia and Indonesia. Primarily, the music or songs are performed as an accompaniment to a theatrical or folk performance. These performances are a central part of the Thai-Muslim lifestyle. The two longstanding entertainment performances are known as the Rong Ngeng and the Li ke Hulu. A third, the Dikia, apart from entertaining the audience also serves to instruct the bride and groom on how to behave well. It refers to the doctrine of Muslim prophets and pleads for their happiness to God. The performances of the Ma'yong and the Sila serve in a general way to build the personal assurance of the audience. For example, they may serve the purpose of socially acknowledging a vow or requesting a cure for an illness.

These Muslim songs and folk performances have been handed down by rote, whether within the artist's family to their offspring or from an unrelated teacher to his student. Currently there are very few recordings or written records of them.

Furthermore, the Wai Khru, with its superstitious faith in the effectiveness of making offerings affecting the outcome of performances or the teacher-student relationship as well as showing respect to ones teacher is profound in its own right. What is more intriguing is its persistence over the ages through many generations and its compatibility with multiple religions. The Wai Khru has comfortably co-existed within both Buddhist and Muslim cultures in the Southern Thai region and may pre-date these formalized religions. In this manner, the Wai Khru has transcended organized religion while serving to fulfill fundamental human needs; as an example, the need for feeling confident and competent in one's profession. (Pre-performance Wai Khru) The need to be socially accepted and a sense of belonging (The Wai Khru of a beginning student towards ones chosen teacher and again in the subsequent Wai Khru to honor them as well as the one marking the status transition from student to professional.)

Additionally, when comparing the Wai Khru rituals related to the honoring of one's teacher between the Thai-Muslim and the Thai-Buddhist performances it is found that they have the same characteristics. Both consist of the concept of a guardian spirit of the land, the concept of a God of music as well as the concept of a single higher power which is held in mind during these rituals, namely the Buddha and Allah. These similarities have shown us something interesting about the influence of religious belief; that is, though one may have different prophets, they both instruct their followers to behave well, to be modest and to be grateful to ones benefactors. 


\section{Comments on technology and knowledge succession}

Over time, many technologies have been developed and consequently the way of transferring or "handing down knowledge" has also changed. The printed word through the cassette tape, the video DVD and more recently internet video has offered both benefits and challenges. In many ways technology has eased the teacher's task and can provide both a more efficient and wider access to those that are interested than ever before. However, at the same time, new technology has provided many other and some would say, "more seductive" performances from abroad to compete with the indigenous offerings. Currently, the emphasis is to focus on skill of performance without regard to the beliefs and their context. It has been reported that the more popular a new artist becomes, the less he will contemplate the traditional roots of his beliefs. As a result, the local belief-based rituals have been in decline. It is feared that the Wai Khru ritual used to honor ones teacher in these Southern folk performances will soon disappear. Together with the loss of the Wai Khru there will be a significant comparable loss in indebtedness from today's youth towards their elders and their own cultural roots.

A challenging adaptation option remains where one can successfully utilize the latest technology to both preserve and present the indigenous culture to current and subsequent generations. The work of recording, disseminating oral and cultural history on DVD, TV, in museums and on the internet all come to mind for Southern Thailand.

\section{References}

Buapim, Sujarit. 1993. Cultural Folklore (วัฒนธรรมพื้นบ้าน). Volume 1.

Bangkok National Cultural Commission, Ministry of Education. (In Thai)

Nuthong, Udom. 1988. Music and Folk play in the Southern Region (ดนตรีและการละเล่น ภาคใต้). Songkla: Department of Thailand Eastern Language, Faculty of Humanities, Srinakharinwirot University, Songkla. (In Thai)

Pongspaiboon, Suthiwongs. 1999. Southern Folk Music (ดนตรีพื้นเมืองภาคใต้). The Southern Thai Culture Encyclopedia (สารานุกรมวัฒนธรรมไทยภาคใต้) $5: 2333-$ 2342. Bangkok: Cultural Encyclopedia Foundation. (In Thai)

Salae, Nureeyan. 1999. Mak Yong (มะโย่ง). The Southern Thai Culture Encyclopedia (สารานุกรมวัฒนธรรมไทยภาคใต้) $12: 5932-$ 5944. Bangkok: Cultural Encyclopedia Foundation. (In Thai) 